\title{
PENGEMBANGAN MODEL PISA BERBASIS BUDAYA MASYARAKAT PADANG BOLAK BERDASARKAN KEMAMPUAN LITERASI MATEMATIS SISWA
}

\author{
Nursahadah $^{1}$, Hasratuddin ${ }^{2}$, Madyunus Salayan ${ }^{3}$ \\ Program Magister Pendidikan Matematika Universitas Muslim Nusantara Al-Washliyah ${ }^{1,3}$, \\ Program Magister Pendidikan Matematika Universitas Negeri Medan² \\ sahadahn80@gmail.com
}

\begin{abstract}
Abstrak
Penelitian ini bertujuan untuk: (1) Mendeskripsikan pengembangan model PISA berbasis budaya masyarakat Padang Bolak dalam meningkatkan kemampuan literasi matematis siswa (2) Menganalisis peningkatan literasi matematis siswa melalui model pisa berbasis budaya masyarakat Padang Bolak (3) Menemukan model PISA berbasis budaya masyarakat Padang Bolak yang efektif untuk meningkatkan kemampuan literasi matematis siswa. Produk yang dihasilkan dalam penelitian adalah instrumen model PISA berbasis budaya masyarakat Padang Bolak. Penelitian ini di lakukan dengan penelitian pengembangan model 4-D. Dengan jenis penelitian pengembangan (Research and Development). Subjek dalam penelitian ini adalah seluruh siswa SMP Manunggal Bagan Batu Rohil Tahun Pelajaran 2018/2019, kelas yang digunakan yaitu VIII sebanyak 30 peserta didik dan 2 guru matematika. objek penelitian adalah pengembangan model PISA berbasis budaya masyarakat Padang Bolak yang berupa buku guru dan siswa pada materi barisan bilangan. Dari hasil penelitian diperoleh instrumen model PISA yang dikembangkan memenuhi kriteria efektif dilihat dari ketuntasan hasil belajar secara klasikal $87,5 \%$, ketuntasan tujuan pembelajaran 76,8\%, respon siswa terhadap instrumen model PISA dalam kategori baik dan positif sebesar $18,75 \%$ dari uji coba I ke uji coba II.
\end{abstract}

Kata Kunci: Pengembangan Instrumen, PISA, Literasi, Budaya Padang Bolak.

\begin{abstract}
This study aims to: (1) Describe the development of the Padang Bolak culture-based PISA model instrument in improving students 'mathematical literacy skills in the material ranks of class VIII (2) Analyzing the increase in students' mathematical literacy through the Pisa cultural-based instrument model of Padang Bolak society on line material class VIII numbers (3) Finding an effective PISA model based on the Padang Bolak culture that is effective in improving students' mathematical literacy skills in class VIII number material. The product produced in the study was the PISA model instrument based on the culture of the people of Padang Bolak. This research was conducted with a research into the development of 4-D models. This research uses the type of research development (Research and Development). The subjects in this study were all students of Manunggal Middle School Bagan Batu Rohil 2018/2019 Academic Year, the class used was VIII as many as 30 students and 2 mathematics teachers. The object of the research was the development of the PISA model based on the culture of the Padang Bolak community in the form of teacher and student books on material sequence numbers. From the results of the study, the developed PISA model instrument meets the effective criteria seen from the completeness of learning outcomes classically $87.5 \%$, the completeness of the learning objectives $76.8 \%$, the students' responses to the PISA model instruments in both good and positive categories are $18.75 \%$ of the test try I to trial II.
\end{abstract}

Keywords: Instrument Development, PISA, Literacy, Padang Bolak Culture. 


\section{PENDAHULUAN}

Tujuan ujian nasional adalah untuk menilai pencapaian Standar Kompetensi Lulusan (SKL) pada mata pelajaran tertentu secara nasional. Berdasarkan PP Nomor 13 Tahun 2015 perubahan kedua atas PP Nomor 19 Tahun 2005 pada Pasal 68 disebutkan hasil ujian nasional digunakan sebagai salah satu pertimbangan untuk tiga hal yaitu pemetaan mutu program dan/atau satuan pendidikan, dasar seleksi masuk jenjang pendidikan berikutnya dan pembinaan dan pemberian bantuan kepada satuan pendidikan dalam upayanya untuk meningkatkan mutu pendidikan. Dapat disimpulkan bahwa Ujian Nasional diperuntukkan untuk mengetahui kemampuan serta mutu siswa dalam menyelesaikan jenjang pendidikan sesuai dengan tujuan pendidikan yang akan dicapai. Salah satu mata pelajaran wajib yang diikuti siswa adalah matematika. Khusus untuk wilayah Sumatera Utara tahun 2016 diketahui bahwa IIUN matematika sebesar $40 \%$ dan UNBK (Ujian Nasional Berbasis Komputer) sebesar $14 \%$ dan berada di peringkat ke - 25. Dalam hal ini Sumatera Utara belum mampu menyamakan kemampuan matematika. Kemampuan matematika yang baik jika siswa mampu memahami soal-soal yang diberikan. Sedangkan soal yang diberikan pada UN adalah soal matematika yang membutuhkan pemahaman literasi matematika yang baik.

Menurut Astuti [1] menjelaskan bahwa literasi matematika diartikan sebagai kemampuan seseorang untuk dapat merumuskan, menerapkan, dan menafsirkan matematika dalam berbagai konteks, termasuk kemampuan melakukan penalaran secara matematis dan menggunakan konsep, prosedur, dan fakta untuk menggambarkan, menjelaskan atau memperkirakan fenomena/kejadian. Kemudian menurut Tasekeb [2] menjelaskan bahwa literasi meliputi seperangkat kemampuan yang kompleks untuk memahami dan menggunakan sistem simbol untuk pengembangan pribadi dan masyarakat. Tujuan utama literasi masih merupakan pembelajaran seumur hidup (livelong education), proses intelektual untuk mendapatkan makna dari interpretasi kritis terhadap teks tertulis atau dicetak. Menurut Amalia [3] juga menjelaskan bahwa literasi matematika adalah keaksaraan menyeluruh yang meliputi berhitung, kesadaran terhadap literasi kuantitatif dan literasi spasial, seperti yang ditunjukkan pada skema berikut ini:

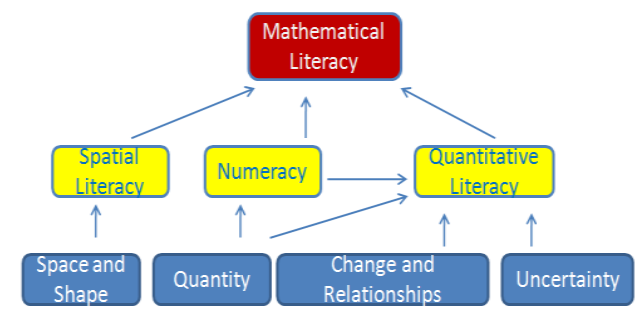

GAMBAR1 Struktur Literasi Matematika menurut De'Lange (Sumber: Syahlan, 2015:41)

Kemudian menurut Damayanti [4] literasi matematika berhubungan dengan masalah "real", dimana masalah biasanya muncul pada sebuah situasi. Siswa harus mampu menyelesaikan masalah nyata (real world problem) yang mengharuskan siswa untuk menggunakan kemampuan dan kompetensi yang telah diperoleh melalui pengalaman di sekolah dan pengalaman sehari-hari. Kemampuan literasi matematika dijadikan salah satu penilaian penting tentang kemampuan peserta didik dalam menyelesaikan soal-soal cerita, sehingga keterbacaan matematika 
dapat diselesaikan dengan baik dan sesuai dengan konteks kehidupan sehari-hari, sehingga dalam setiap langkah menyelesaikan soal, setiap peserta didik mampu memahami dan memecahkan masalah.

Kemudian hal ini dipaparkan juga oleh PISA (Programme for International Student Assessment) dan TIMSS (Trend in International Mathematics and Science Study) bahwa hampir semua siswa Indonesia hanya menguasai pelajaran sampai level 3 saja, sementara Negara lain banyak yang sampai level 4, 5 dan 6. PISA (Programme for International Student Assesment merupakan suatu studi bertaraf internasional yang diselenggarakan oleh OECD (Organization for Economic Cooperation and Development) yang mengkaji kemampuan literasi siswa pada rentang usia 15-16 tahun yang diikuti oleh beberapa negara peserta, termasuk Indonesia. Menurut Anisah [5] menjelaskan bahwa konten PISA matematika adalah berkaitan dengan kemampuan siswa untuk menganalisis, mengemukakan alasan dan mengkomunikasikan ide-ide efektif karena mereka menggambarkan, merumuskan, memecahkan dan menafsirkan soal matematika dalam berbagai situasi. Penilaian PISA matematika berfokus pada masalah di dunia nyata, bergerak di luar macam situasi dan masalah yang biasanya dihadapi di dalam kelas sekolah.

Dengan demikian untuk mengejar ketertinggalan pendidikan di Indonesia yang mengacu pada PISA dan TIMSS serta tuntutan zaman yang terus berkembang, maka perlu adanya perbaikan kurikulum, khususnya pada pendidikan matematika. Hasil penelitian Sumarni [6] juga menegaskan bahwa kemampuan tinggi pada soal level 3 tidak mengalami kesulitan sedangkan pada soal level 4 diperoleh 2 subjek mengalami kesulitan menerjemahkan masalah ke dalam model matematika, kesulitan dalam menentukan strategi dan kesulitan dalam melakukan prosedur matematika dan 1 subjek tidak mengalami kesulitan. Sedangkan subjek dengan kemampuan sedang dan rendah pada soal level 3 maupun level 4 mengalami kesulitan yang sama yaitu kesulitan dalam memahami masalah, kesulitan menerjemahkan masalah ke dalam model matematika, kesulitan dalam menentukan strategi dan kesulitan dalam melakukan prosedur matematika. Kemudian menurut Rifai [7] bahwa kemampuan literasi matematika siswa SMP Negeri di Kabupaten Bantul masih terkategori sangat rendah, untuk domain konten bilangan, peluang dan data termasuk kategori sedang, sedangkan untuk konten aljabar termasuk dalam kategori rendah, dan geometri termasuk kategori sangat rendah dan untuk domain proses memformulasikan situasi matematika termasuk kategori tinggi, untuk domain proses menggunakan konsep, fakta, prosedur, dan penalaran matematika termasuk kategori rendah dan pada domain proses menafsirkan, menerapkan, dan mengevaluasi hasil matematika termasuk kategori sangat rendah.

Dengan demikian permasalahan tersebut dapat diselesaikan dengan mengembangkan instrumen model PISA. Dengan mengintegrasikan dengan kebudayaan sekitar siswa, sehingga memudahkan setiap siswa menyelesaikan setiap soal-soal yang diberikan, pengembangan instrumen model PISA berbasis budaya masyarakat Padang Bolak menjadi salah satu melatih dan meningkatkan literasi matematika siswa. Padang bolak adalah salah satu suku di Sumatera Utara dengan banyak keragaman budaya seperti candi dan tari tor- tor. Banyak penelitian yang telah dilakukan dalam mengembangkan instrumen model PISA. Seperti halnya menurut Martani [8] bahwa hasil tes secara keseluruhan dengan nilai ratarata kemampuan penalaran matematis 68,3, termasuk pada kategori kemampuan 
penalaran matematis yang baik, walaupun masih ada siswa yang memiliki penalaran matematis cukup dan kurang baik. Namun dari hasil ini juga dapat dikatakan bahwa soal model PISA yang dikembangkan dikategorikan kriteria valid dan praktis serta memiliki efek potensial terhadap penalaran matematis siswa.

Selanjutnya hal ini juga dikemukan oleh Putra [9] menjelaskan bahwa hasil yang diperoleh 4 butir soal matematika model PISA konten bilangan yang valid dan praktis, soal dinyatakan valid dari segi konten, konstruk, dan bahasa berdasarkan dari komentar atau saran expert dan hasil analisis kuantitatif pada uji validitas kriteria; sedangkan soal dinyatakan praktis karena soal bisa dipahami oleh siswa dan dapat diimplementasikan dengan baik; dan soal matematika model PISA konten bilangan memiliki efek potensial terhadap siswa; berdasarkan hasil tes dan angket semua Kemampuan Dasar Matematika (KDM) dilibatkan siswa dalam menjawab soal. Berdasarkan uraian diatas maka diduga dengan pengembangan instrumen model PISA berbasis budaya masyarakat Padang Bolak dapat meningkatkan literasi matematika.

Penelitian ini juga didukung oleh penelitian Sirait [10] menyatakan kemampuan literasi matematis siswa ditinjau dari kemampuan pemecahan masalah siswa SMP di Pontianak berdasarkan hasil analisis data. Siswa yang memenuhi kriteria aspek penalaran adalah siswa yang berada pada kelompok pemecahan masalah tinggi. Kemudian Charmila [11] menyatakan pengembangan soal matematika model PISA menggunakan konteks Jambi, berdasarkan hasil analisis diperoleh bahwa soal yang dikembangkan memiliki beberapa efek potensial yaitu memunculkan pelibatan kemampuan dasar matematis yang beragam pada proses penyelesaiannya. Selain itu, mampu menarik minat dan memotivasi siswa sehingga tertantang menyelesaikan soal. Soal-soal ini juga memberikan stimulus kepada siswa untuk berpikir kritis menggunakan penalaran sendiri dalam penyelesaiannya. Oleh karena itu peneliti akan melakukan penelitian tentang "Pengembangan Model Pisa Berbasis Budaya Masyarakat Padang Bolak Berdasarkan Kemampuan Literasi Matematis Siswa”.

\section{METODE}

Penelitian ini dilaksanakan di kelas VIII SMP Manunggal Bagan Batu Rohil Tahun Pelajaran 2018/2019 pada materi barisan bilangan. Penelitian ini menggunakan jenis penelitian pengembangan (Research and Development). Pada metode penelitian dan pengembangan ini menggunakan model 4-D. Model pengembangan 4D terdiri atas 4 tahap utama yaitu: (1) Define (Pendefinisian); (2) Design (Perancangan); (3) Develop (Pengembangan); dan (4) Disseminate (Penyebaran). Bertujuan untuk menghasilkan produk berupa instrumen model PISA berbasis budaya masyarakat Padang Bolak. Produk yang dikembangkan kemudian diuji kelayakannya dengan validitas dan uji coba produk untuk mengetahui sejauh mana peningkatan literasi matematis siswa setelah pembelajaran menggunakan model PISA berbasis budaya masyarakat Padang Bolak pada materi barisan bilangan.

Penelitian ini dianalisis dengan uji beda menggunakan uji t yaitu Indepedent sample t- test (Uji t dua sampel bebas) dan menggunakan IBM SPSS 22 for windows. Dan juga mengukur kevalidan, kepraktisan dan efektifan instrumen model PISA yang akan dikembangkan dengan menyusun dan mengembangkan 
instrumen penelitian. Peningkatan literasi matematis dengan instrumen yang disediakan dihitung menggunakan nilai gain setiap sampel. Instrumen keefektifan bahan ajar terdiri dari lembar observasi aktivitas peserta didik, tes kemampuan pemecahan masalah matematis, dan angket kemandirian belajar peseta didik. Penelitian in dikatakan berhasil jika instrumen model PISA berbasis budaya masyarakat Padang Bolak memenuhi kriteria valid, praktis dan efektif.

\title{
HASIL DAN PEMBAHASAN
}

\section{Hasil Penelitian}

Pengembangan ini menggunakan model 4-D dari Thiagarajan, Semmel dan Semmel yang telah dimodifikasi. Hasil pengembangan pembelajaran berupa Rencana Pelaksanaan Pembel ajaran (RPP), Lembar Kegiatan Siswa (LKS) dan Instrumen Model PISA Kemampuan Literasi Matematis (IMPKLM).

Berikut beberapa tampilan dari hasil pengembangan pembelajaran tersebut.

\section{RENCANA PELAKSANAAN PEMBELAJARAN}

(RPP)

Sekolah

Mata Pelajaran

Kelas/Semester

Materi Pokok

Alokasi Waktu

\author{
: SMP Manunggal Bagan Batu Rohil \\ : Matematika \\ : VIII/Semester Genap \\ : Barisan Bilangan \\ : 2 Pertemuan x 2 Jam Pelajaran @ 40 Menit
}

\section{A. Kompetensi Inti}

- KI-1 dan KI-2:Menghayati dan mengamalkan ajaran agama yang dianutnya. Menghayati dan mengamalkan perilaku jujur, disiplin, santun, peduli (gotong royong, kerjasama, toleran, damai), bertanggung jawab, responsif, dan pro-aktif dalam berinteraksi secara efektif sesuai dengan perkembangan anak di lingkungan, keluarga, sekolah, masyarakat dan lingkungan alam sekitar, bangsa, negara, kawasan regional, dan kawasan internasional".

- KI 3: Memahami dan menerapkan pengetahuan (faktual, konseptual, dan prosedural) berdasarkan rasa ingin tahunya tentang ilmu pengetahuan, teknologi, seni, budaya terkait fenomena dan kejadian tampak mata

- KI4: Mengolah, menyaji dan menalar dalam ranah konkret (menggunakan, mengurai, merangkai, memodifikasi, dan membuat) dan ranah abstrak (menulis, membaca, menghitung, menggambar, dan mengarang) sesuai dengan yang dipelajari di sekolah dan sumber lain yang sama dalam sudut pandang/teori

B. Kompetensi Dasar dan Indikator Pencapaian Kompetensi

\begin{tabular}{ll}
\hline \multicolumn{1}{c}{ Kompetensi Dasar } & Indikator \\
\hline $\begin{array}{l}\text { Menentukan pola pada barisan bilangan } \\
\text { dan barisan konfigurasi objek }\end{array}$ & $\begin{array}{l}\text { - Menilai pola pada barisan bilangan } \\
\text { - menilai konfigurasi barisan pada objek } \\
\\
\text { masyarakat Padang Bolak } \\
\text { - Memformulasikan rumus pola barisan bilangan } \\
\text { dan konfigurasi objek masyarakat padang bolak }\end{array}$ \\
\hline $\begin{array}{l}\text { Menyelesaikan masalah yang berkaitan } \\
\text { dengan pola pada barisan bilangan }\end{array}$ & $\begin{array}{l}\text { Mengoperasikan rumus yang terkait dengan pola } \\
\text { pada barisan bilangan berdasarkan soal-soal } \\
\text { dikaitkan dengan masyarakat Padang Bolak }\end{array}$ \\
& $\begin{array}{l}\text { Menyelesaikan masalah yang pola barisan } \\
\text { bilangan sesuai dengan soal masyarakat Padang } \\
\text { Bolak }\end{array}$ \\
\hline
\end{tabular}




\section{Tujuan Pembelajaran}

Setelah mengikuti proses pembelajaran, peserta didik diharapkan dapat:

- Menilai pola pada barisan bilangan

- menilai konfigurasi barisan pada objek budaya masyarakat Padang Bolak

- Memformulasikan rumus pola barisan bilangan dan konfigurasi objek budaya masyarakat padang bolak

- Mengoperasikan rumus yang terkait dengan pola pada barisan bilangan berdasarkan soalsoal dikaitkan dengan masyarakat Padang Bolak

- Menyelesaikan masalah yang pola barisan bilangan sesuai dengan soal budaya masyarakat Padang Bolak

\section{Hasil Lembar Kegiatan Siswa(LKS)}

\section{LEMBAR KERJA SISWA (LKS) \\ MATERI BARISAN BILANGAN}

Tujuan yang diharapkan tercapai adalah mampu meningkatkan literasi matematis, diantaranya adalah:

a. Siswa mampu menggunakan keterampilannya dengan baik dan mengemukakan alasan dan pandangan yang fleksibel sesuai dengan konteks. Mereka dapat memberikan penjelasan dan mengkomunikasikannya disertai argumentasi berdasar pada interpretasi dan tindakan mereka pada materi barisan bilangan (Level 4)

b. Siswa mampu menginterpretasikan dan menggunakan representasi berdasarkan sumber informasi yang berbeda dan mengemukakan alasannya. Mereka dapat mengkomunikasikan hasil interpretasi dan alasan mereka (Level 3)

c. Siswa mampu mengerjakan algoritma dasar, menggunakan rumus, melaksanakan prosedur sederhana. Mereka mampu memberikan alasan secara langsung dan melakukan penafsiran harafiah. (Level 2)

d. Siswa mampu mengidentifikasi informasi dan menyelesaikan prosedur rutin menurut instruksi eksplisit. Mereka dapat melakukan tindakan sesuai dengan stimuli yang diberikan (Level 1)

\section{A. Soal dan Lembar Kerja}

1. Masyarakat padang bolak sangat senang mencari buah balakka, yang kayunya digunakan untuk memasak holat. Holat sangat khas di wilayah Padang Bolak dengan menggunakan ikan bakar. Dalam pemasakannya umak membolak balik ikan mas yang dibayar sebanyak dua kali setiap 20 menit. Nah umak menggunakan ikan mas sebanyak 15 ikan mas. Sekarang coba kamu hitung berapa kali umak membolak balik ikan mas setelah 2 jam?

Penyelesaian:

Identifikasi Informasi:

2. Tahukah anda Candi yang terdapat di Padang Bolak 


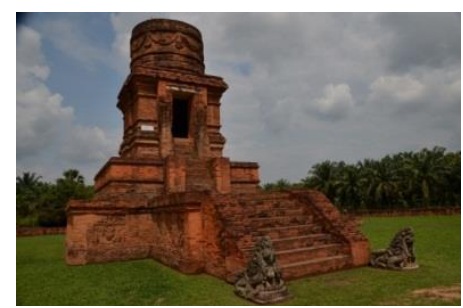

Jika candi disusun dengan pola dibawah ini:

\section{$\begin{array}{lllll}\text { Pola ke- } 1 & 2 & 3 & 4\end{array}$}

Nah sekarang berapakah jumlah batu yang akan diperlukan pada susunan ke - 20. Ayo sekarang kamu selesaikan!

Penyelesaian:

\begin{tabular}{|l|}
\hline Identifikasi Informasi: \\
\hline Penggunaan Rumus dan Prosedur \\
\hline Representasikan dengan mengemukan alasan dalam menjawab \\
\hline Mengkomunikasikan hasil dengan menggunakan argumen dalam menyelesaikan setiap \\
barisan bilangan
\end{tabular}

\section{Format buku guru}
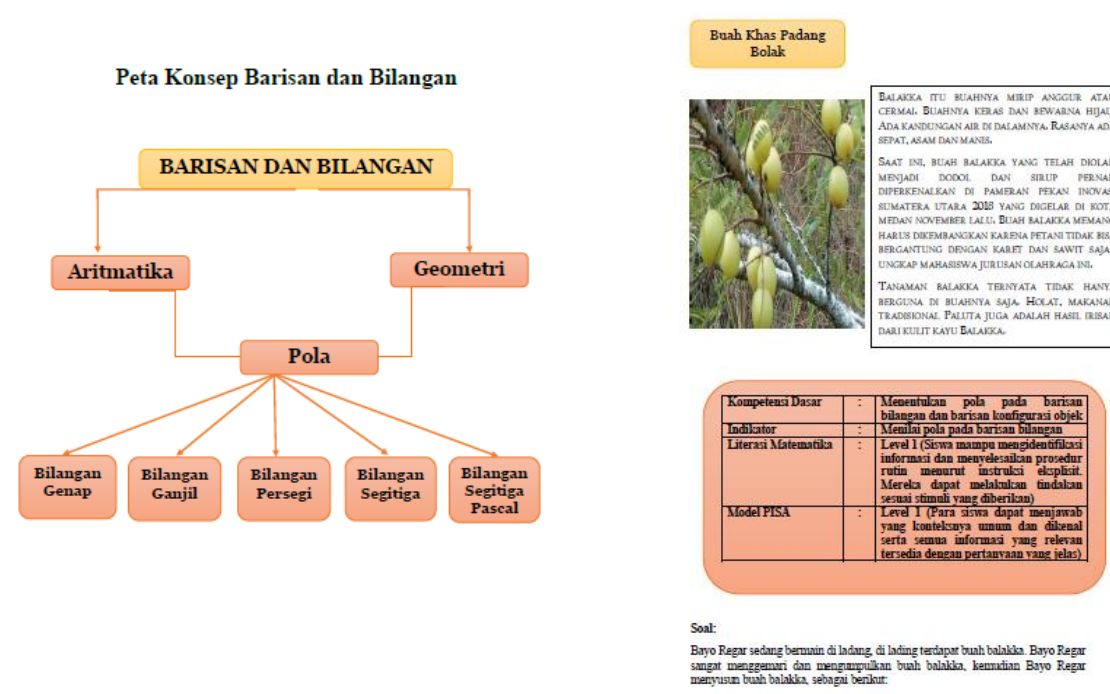


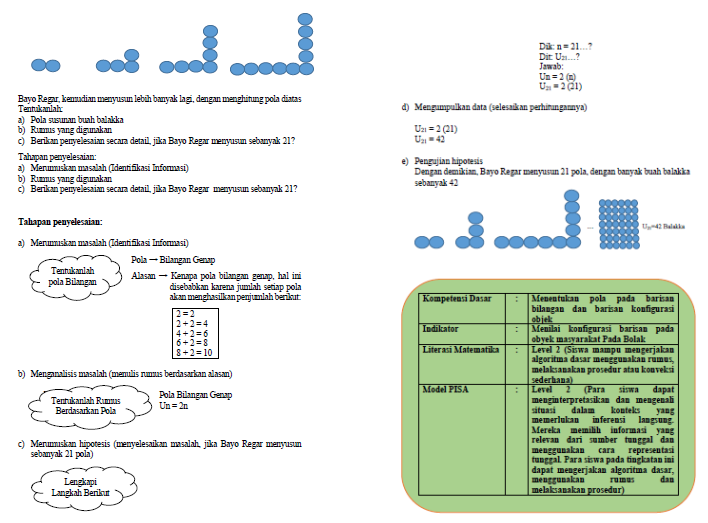

\section{Instrumen Model PISA Berbasis Budaya Masyarakat Padang Bolak}

Dalam hal ini, instrumen Model PISA yang digunakan dalam Penelitian ini hanya pada level 4, hal ini sudah tercantum pada batasan masalah dan indikator pencapaian pada kemampuan literasi matematika peserta didik. Format instrumen Mode PISA, dapat diperlihatkan sebagai berikut:

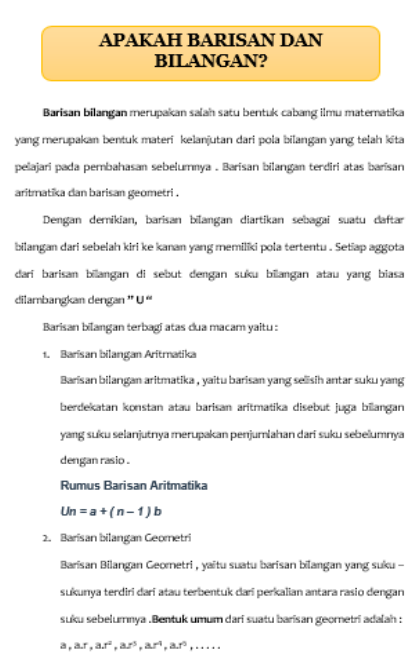

Buah Khas Padang Bolak
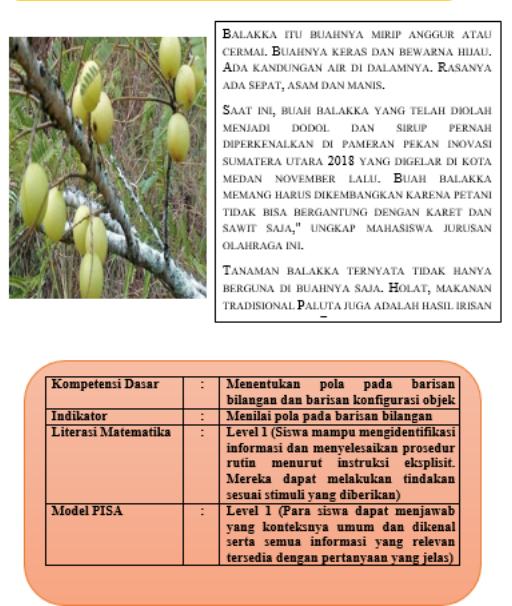

MEDIA PEMBELAJARAY BARISAN DAN BILANGAY

a. Pola Bilangan Genap dan Bilangan Ganjil

Sebelum kita belajar lebih jauh, untuk mendalami pola bilangan lakukan

kegiatan berkut ini

Bahan : Satu lembar kertas

1. Lipattah satu lembar kertas (berbentuk persegipanjang) sehingga menjadi 2 bagian yang sama. Guntinglah menurut lipatan tersebut. Ada berapa banyak potongan kertas?

2. Susunlah semua potongan kertas tersebut sehingga saling menutup. Lipatlah susunan kertas tersebut menjadi 2 bagian yang sama, kemudian guntinglah menurut lipatan tersebut. Ada berapa banyak potongan kertas sekarang? Catatlah banyaluyya potongan kertas yang terjadi pada tabel dib bawah.

Sost:

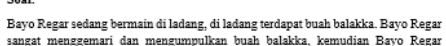

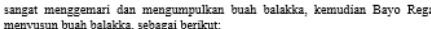

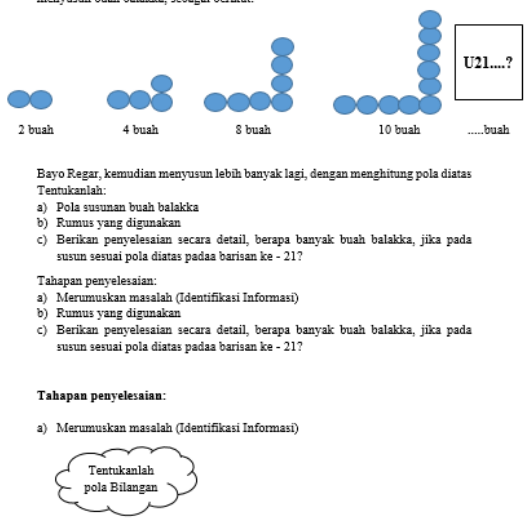




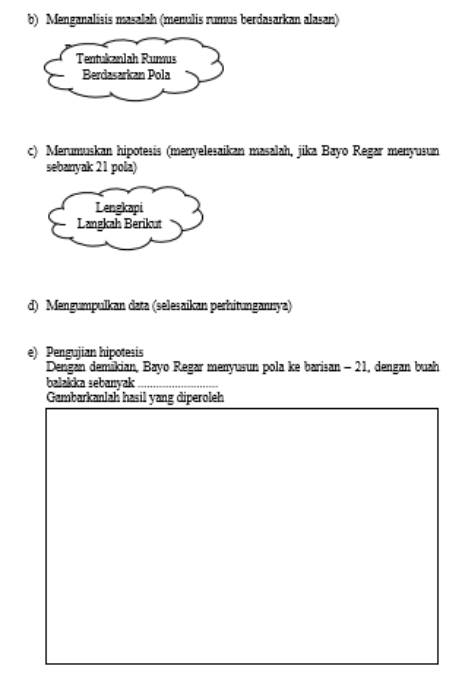

Dengan demikian, keseluruhan perangkat pembelajaran disesuaikan dengan pendekatan pemecahan masalah agar menjadi satu kesatuan untuk kemudian diharapkan penerapannya berdampak pada peningkatan kemampuan literasi matematis siswa SMP.

\section{Pembahasan}

Setelah dilakukan desain dan pengembangan produk sesuai dengan kebutuhan peserta didik dalam meningkatkan kemampuan literasi matematika, sehingga produk berupa RPP, LKS, buku guru (alternatif jawaban Model PISA) dan buku instrumen model PISA berbasis budaya masyarakat Padang Bolak. Selanjutnya produk dilakukan pengujian oleh validator ahli, sebanyak dua kali validasi, sehingga diperoleh:

Produk dilakukan tahapan validasi, hasil validasi oleh tim ahli pada tahapan pertama nilai rata-rata yang diperoleh sebesar 2,92 artinya aspek kelayakan isi masih kurang baik, sehingga ada perbaikan. Selanjutnya perbaikan dalam aspek pendukung penyajian soal dan alternatif, nilai rata-rata yang diperoleh sebesar 2,80 artinya aspek kelayakan penyajian masih kategori kurang baik, sehingga ada perbaikan yang harus dilakukan Dengan demikian, untuk proses tahapan validasi ahli tahap I, validator memberikan kesimpulan instrumen Model PISA berbasis budaya masyarakat Padang Bolak dapat digunakan dengan revisi. Tahapan kedua dilakukan validasi kembali dan menghasilkan nilai rata-rata yang diperoleh sebesar 3,17 artinya aspek kelayakan isi sudah pada kategori baik, selanjutnya nilai ratarata yang diperoleh sebesar 3,30 artinya aspek kelayakan isi sudah pada kategori baik dan nilai rata-rata yang diperoleh sebesar 3,0 artinya aspek kelayakan bahasa menurut BSNP sudah pada kategori baik.Validasi selesai sampai tahapan kedua. Validasi telah dilalui dan dinyatakan layak dengan kategori baik.

Kemudian uji normalitas bernilai 0,070 dengan syarat yang diterima jika Sig > 0,05 sehingga data berdistribusi normal. Selanjutnya uji homogenitas data menggunakan IBM SPSS 23 for windows, dengan menggunakan Uji Levene Statistic Sig bernilai 0,140 sehingga diperoleh data homogen karena 0,140>0,05. Kemudian Pengujian selanjutnya dilakukan untuk mengetahui keberhasilan pengembangan instrumen Model PISA berbasis budaya masyarakat Padang Bolak dalam meningkatkan kemampuan lietrasi matematis siswa yaitu diperoleh nilai 
sebesar 0,000, dengan demikian 0,000 > 0,05 artinya Ha diterima yaitu instrumen model PISA berbasis budaya masyarakat Padang Bolak mampu meningkatkan kemampuan literasi matematis siswa pada materi barisan bilangan. Dalam hal ini juga ditegaskan bahwa perbedaan rata-rata dengan asumsi yang sama adalah 19,48367, perbedaan standar eror sebesar 2,13074 serta perbedaan secara signifikan ditunjukkan dengan nilai terendah 15,21853 dan tertinggi 23,74881.

Peningkatan juga diperlihatkan dengan hasil gain dalam penelitian. Diketahui bahwa kelas eksperimen memperoleh nilai gain sebesar 1,39 dengan kategori tinggi sedangkan kelas kontrol hanya 0,34 dengan demikian disimpulkan bahwa dengan pendekatan berbasis masalah dengan produk yang telah divalidasi dapat meningkatkan kemampuan literasi matematika peserta didik pada soal-soal instrumen model PISA berbasis budaya masyarakat Padang Bolak.

Hal ini juga dapat dilihat pada gambar grafik batang dibawah ini :

Dari gambar grafik batang, tentang keberhasilan siswa dalam menjawab produk instrumen yang disajikan:

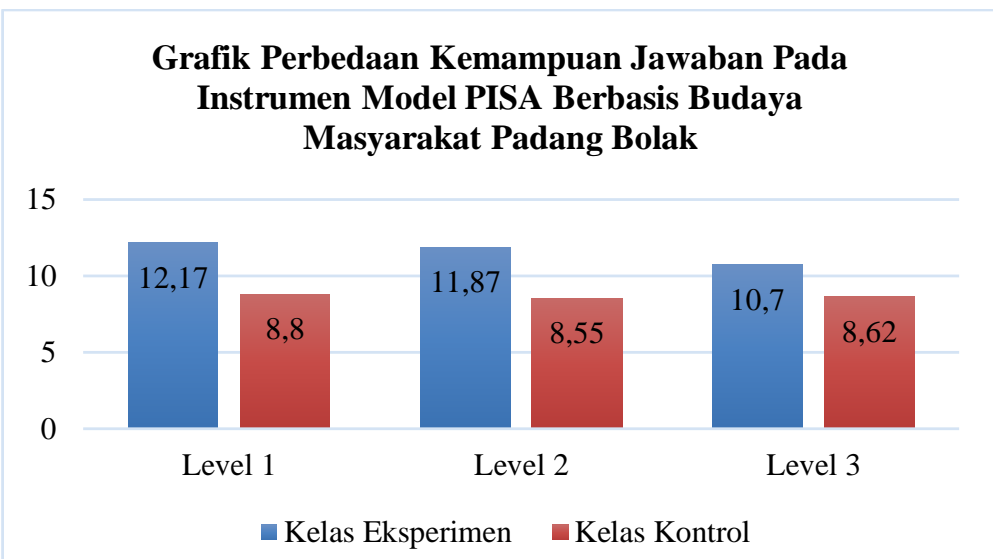

GAMBAR 2 Grafik Batang Perbedaan Kemampuan Jawaban Pada Instrumen Model PISA Berbasis Budaya Masyarakat Padang Bolak

Dari Gambar 2 grafik batang, diketahui bahwa kemampuan siswa dengan menggunakan produk pengembangan instrumen lebih baik dibandingkan dengan siswa yang hanya diberikan soal-soal yang terdapat dalam LKS yang diberikan oleh pihak sekolah, keberhasilan ini dapat dirincikan yaitu pada level 1 diketahui kelas eksperimen dengan menggunakan produk memperoleh nilai rata-rata sebesar 12,17 artinya para siswa dapat menjawab pertanyaan yang konteksnya umum dan dikenal serta semua informasi yang relevan tersedia dengan pertanyaan yang jelas. Pada level 2 diketahui bahwa kelas eksperimen memperoleh nilai rata-rata 11,87 artinya para siswa pada tingkatan ini dapat mengerjakan algoritma dasar, menggunakan rumus, melaksanakan prosedur atau konvensi sederhana, mereka mampu memberikan alasan secara langsung dan melakukan penafsiran harafiah. Pada level 3 diketahui bahwa nilai rata-rata sebesar 10,70 artinya melaksanakan prosedur dengan baik, termasuk prosedur yang memerlukan keputusan secara berurutan, siswa dapat memilih dan menerapkan strategi memecahkan masalah yang sederhana, dengan demikian siswa mampu mengisi setiap langkah-langkah yang disajikan dalam produk yang diberikan.

Dengan demikian, dapat disimpulkan bahwa siswa sudah mampu menyelesaikan instrumen Model PISA berbasis budaya masyarakat Padang Bolak. 
Hasil ini ditunjukkan pada gambar grafik :
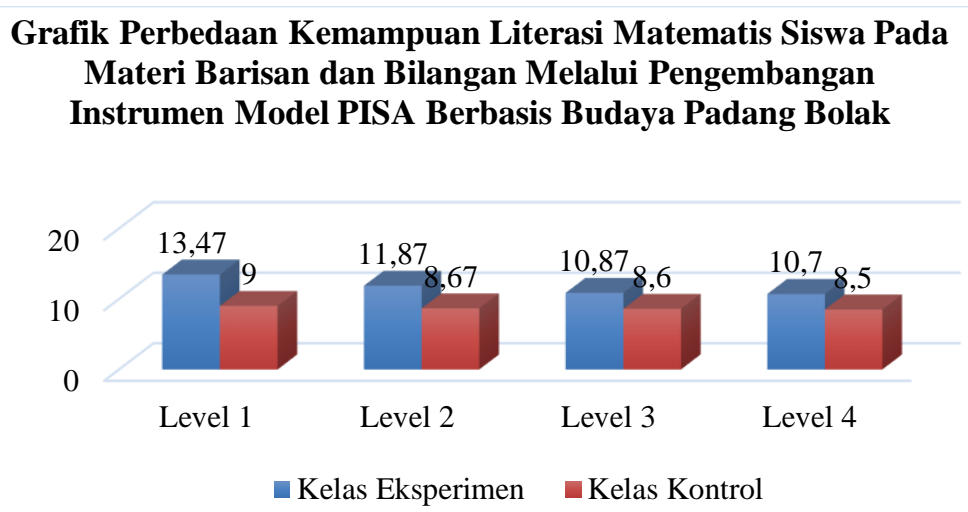

GAMBAR 3 Grafik Batang Perbedaan Kemampuan Literasi Matematis Siswa Pada Materi Barisan dan Bilangan Melalui Pengembangan Instrumen Model PISA Berbasis Budaya Masyarakat Padang Bolak

Dari gambar 3, diketahui dengan jelas bahwa kelas eksperimen yang menggunakan produk baru yang telah di validasi, memiliki kemampuan literasi matematis lebih baik dalam setiap level. Level 1 dengan nilai rata-rata pada kelas eksperimen sebesar 13,47, level 2 dengan nilai rata-rata pada kelas eksperimen sebesar 11,87 artinya siswa mampu siswa mampu mengerjakan algoritma dasar menggunakan rumus, melaksanakan prosedur atau konveksi sederhana, setiap soal barisan bilangan, memberikan kemudahan siswa menentukan rumus apa saja yang akan diselesaikan, level 3 dengan nilai rata-rata pada kelas eksperimen sebesar 10,87 artinya siswa mampu menginterpretasikan dan menggunakan representasikan berdasarkan sumber informasi yang berbeda dan menggunakan alasan mereka serta mengkomunikasikan hasil interprestasi, level 4 dengan nilai rata-rata kelas eksperimen sebesar 10,70 artinya siswa mampu menggunakan keterampilan dengan baik dan mengemukakan alasan dan pandangan fleksibel sesuai dengan konteks dan mereka dapat memberikan penjelasan dan mengkomunikasikan disertai argument berdasarkan pada interprestasi dan tindakan mereka pada materi barisan dan bilangan, terlihat antusias mengemukan didepan kelas, sehingga memotivasi siswa lain dalam ikut menjawab setiap permasalahan yang disajikan.

Kelas eksperimen nilai $\mathrm{N}$-gain sebesar 1,39 dengan kategori Tinggi sedangkan kelas kontrol dengan nilai $\mathrm{N}$-Gain sebesar 0,34 dengan kategori sedang. Terlihat jelas instrumen dengan menggunakan soal sesuai dengan masyarakat sekitar, memudahkan siswa memahami soal yang diberikan dan langkah-langkah menyelesaikan menjadi salah satu kemudahan siswa mengenal dan menyelesaikan permasalahan dengan baik dan tepat. Dengan demikian, dengan menggunakan buku instrumen model PISA berbasis budaya masyarakat Padang Bolak mampu meningkat kemampuan literasi matematis siswa dalam memecahkan masalah. Tingkat ketuntasan kemampuan literasi matematis siswa minimal $80 \%$ siswa yang mengikuti pembelajaran mampu mencapai nilai $\geq 70$ yaitu pada kategori nilai baik. Dengan menyebarkan angket respon siswa terhadap komentar siswa menggunakan produk pengembangan instrumen Model PISA berbasis budaya msayarakat Padang Bolak,diketahui dari hasil yang diperoleh 25 siswa menyatakan positif terhadap produk dalam pembelajaran matematika artinya $83,3 \%$ siswa memberikan respon positif. 
Keefektifan pengembangan produk berupa buku latihan dan altrenatif jawaban instrumen model PISA berbasis budaya masyarakat Padang Bolak pada materi barisan dan bilangan. Produk yang disajikan dengan kekhasan masyarakat Padang Bolak dalam kehidupan sehari-hari baik tumbuhan khas seperti Balakka atau Pakkat, makanan khas seperti Holat atau kekhasan dalam proses pernikahan, setiap soal yang disajikan dengan soal barisan dan bilangan yang diintegrasikan dengan budaya masyarakat Padang Bolak, sehingga menumbuhkan kebiasaan membaca siswa terutama menjadikan siswa dalam meningkatkan kemampuan menemukan hingga menyelesaikan setiap masalah yang disajikan. Dengan demikian, dapat ditegaskan bahwa produk pengembangan instrumen model PISA berbasis budaya masyarakat Padang Bolak, mampu berkontribusi dan efektif digunakan dalam meningkatkan kemampuan literasi matematis siswa.

\section{KESIMPULAN}

Pengembangan (validitas) instrumen model PISA berbasis budaya masyarakat Padang Bolak dalam meningkatan kemampuan literasi matematis siswa pada materi barisan bilangan telah dinyatakan valid oleh tim validasi ahli. Terdapat peningkatan kemampuan literasi matematis melalui instrumen model PISA berbasis budaya masyarakat Padang Bolak dengan hasil yang diperoleh $\mathrm{N}$-gain sebesar 1,39 dengan kategori tinggi .Instrumen model PISA berbasis budaya masyarakat Padang Bolak untuk meningkatan kemampuan literasi matematis siswa pada materi barisan bilangan, dinyatakan efektif, hal ini diketahui oleh persentase ketuntasan sebesar $86,67 \%$ dan $83,3 \%$ siswa memberikan respon positif.Kesimpulan harus secara jelas mengindikasikan hasil-hasil penelitian yang diperoleh, kelebihan dan kekurangannya, serta kemungkinan pengembangan selanjutnya.

\section{DAFTAR RUJUKAN}

[1] Astuti, P. (2018, February). Kemampuan Literasi Matematika dan Kemampuan Berpikir Tingkat Tinggi. In PRISMA, Prosiding Seminar Nasional Matematika (Vol. 1, pp. 263-268).

[2] Tasekeb, D., Wardono, W., \& Mulyono, M. (2019). Kemampuan Literasi Matematika Ditinjau dari Kemandirian Belajar pada Pembelajaran MEA Pendekatan Saintifik. In Prosiding Seminar Nasional Pascasarjana (PROSNAMPAS) (Vol. 2, No. 1, pp. 559-563).

[3] Amalia, R., Hardani, H., \& Yusniar, Y. (2018). Penerapan Problem Based Learning Yang Dipadukan Dengan Model Team Games Tournament Untuk Meningkatkan Motivasi Belajar Dan Kemampuan Literasi Matematis Siswa SMP Negeri 1 Langsa. Journal of Basic Education Studies, 1(1), 15-25.

[4] Damayanti, N. K. A., Suarsana, I. M., \& Suryawan, I. P. P. (2017). Peningkatan Kemampuan Literasi Matematika Siswa Melalui Penerapan Collaborative Learning Model. Wahana Matematika dan Sains: Jurnal Matematika, Sains, dan Pembelajarannya, 11(1), 33-42.

[5] Anisah, A., Zulkardi, Z., \& Darmawijoyo, D. (2013).

[6] Sumarni, M. D. M., \& Side, S. Analisis Kesulitan Dalam Menyelesaikan Soal Literasi Matematika Ditinjau Dari Kemampuan Awal Siswa Kelas VIII SMP Negeri 1 Makassar.

[7] Rifai, R., \& Wutsqa, D. U. (2017). Kemampuan literasi matematika siswa SMP negeri SeKabupaten Bantul. Jurnal Pendidikan Matematika dan Sains, 5(2), 152-162.

[8] Martani, B. T., \& Murtiyasa, B. (2016). Pengembangan Soal Model Pisa Pada Konten Quantity Untuk Mengukur Kemampuan Penalaran Matematis Siswa.

[9] Putra, Y. Y., Zulkardi, Z., \& Hartono, Y. (2016). Pengembangan Soal Matematika Model PISA Konten Bilangan untuk Mengetahui Kemampuan Literasi Matematika Siswa. Jurnal Elemen, 2(1), 14-26. 
[10] Sirait, M. A., Hartoyo, A., \& Suratman, D. (2016). Kemampuan Literasi Matematis Siswa Ditinjau Dari Kemampuan Pemecahan Masalah Siswa SMP Di Pontianak (Doctoral dissertation, Tanjungpura University).

[11] Charmila, N., Zulkardi, Z., \& Darmawijoyo, D. (2016). Pengembangan soal matematika model PISA menggunakan Konteks Jambi. Jurnal Penelitian dan Evaluasi Pendidikan, 20(2), 198207. 